\title{
An Introduction to Celestial Navigation
}

"You know your place in the sky, You hold your course and your aim; And each in your season, Returns and returns, And is always the same"

EXCERPT FROM "STARS" FROM THE MUSICAL

Les Miserables by Claude-Michel Schönberg

E orestry and field work go hand-inI hand. As I write this my fellow interns are on their way to the field to assist in data collection at an enhanced forest productivity research site. They have taken with them maps, compasses, GPS units, batteries, radio and satellite phones-everything necessary to ensure a safe return. However, not every trip into the woods goes exactly as planned. Unforeseen delays can be the result of a myriad of events in a day's work-equipment malfunction, blowdown, slash, uncooperative weather conditions-the list goes on. No matter

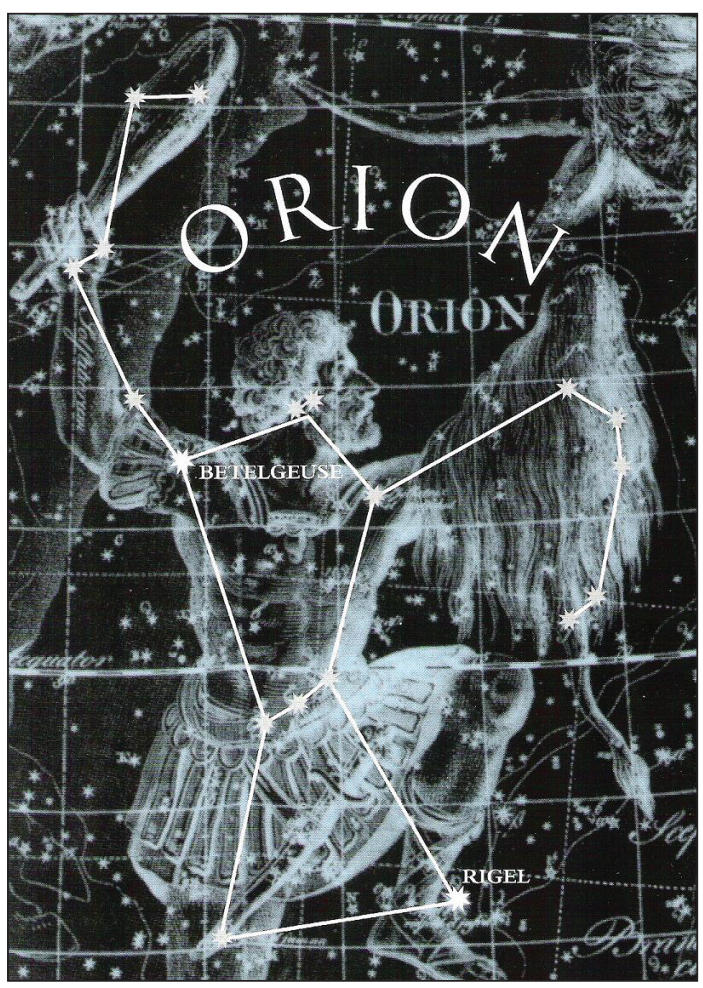

Using the pointer stars of the Big Dipper, one can locate Polaris, which will always be five times the distance away from the Big Dipper as the pointer stars are from each other. True north is always located directly beneath Polaris. safely. how prepared one is, sometimes we cannot win. A delay in the field can amount to a few extra minutes or it can turn into hours, even a night spent out in the woods. Just like being prepared was the key to success before leaving the office, being equally prepared at this point will be the key to leaving the woods

The art of celestial navigation or astronavigation is a technique that has been evolving over the course of thousands of years since people first took to the open seas. Sailors began using the stars to maintain their bearings to navigate at night and determine their position at sea. The

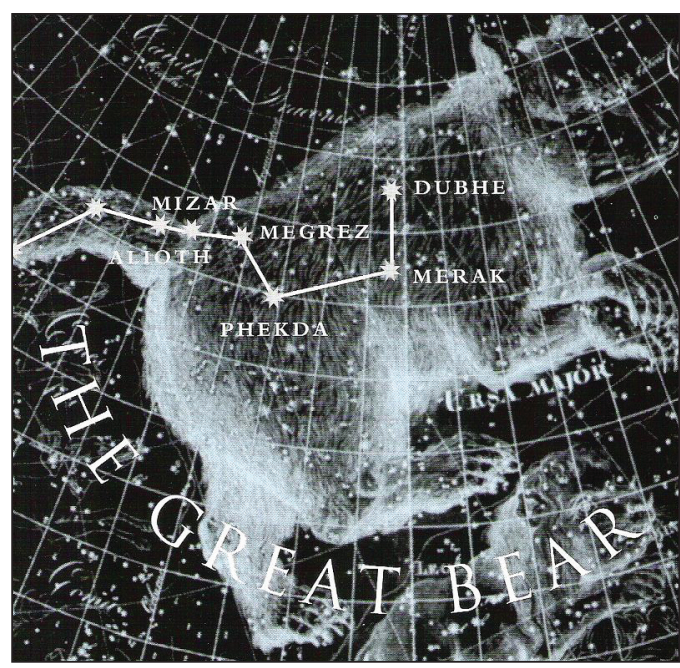

Artist's depiction of the constellations Ursa Major: the Big Bear and Ursa Minor: the Little Bear, highlighting Polaris, or the North Star.

techniques they perfected can still be used today when modern technologies fail.

Most people can identify the "Big Dipper" rotating through the northern hemisphere. This seven-star constellation, part of the larger Ursa Major (the Big Bear) constellation, rises in the northeastern sky at sunset and sets low in the northwest sky at dawn, allowing it to be easily seen throughout the night.Using the "pointer stars" (the two stars that a liquid would run off if you were to tip the dipper), one can locate the North Star or Polaris. Polaris, part of the "Little Dipper" or Ursa Minor (the Little Bear) constellation, will always be five times the distance between the pointer stars in the direction that they point (up away from the pan). True north lies directly under the North Star. Rotating counterclockwise about this star, the Big Dipper will sometimes appear upside down or on its side but its relationship with Polaris remains constant and will always dependably point the way North.

Should the Big Dipper be too low in the sky to be seen or is obscured by trees or clouds the constellation known as Cassiopeia or the "Vain Queen" can also be used to locate the North Star. This five star constellation is located in the northern hemisphere, positioned directly opposite the North Star from the Big Dipper, therefore placing it high in the night sky when the Big Dipper is low. Located in the haze of the Milky Way, this W-shaped or "zig-zag" constellation is easily recognizable and its middle star acts as an arrow head, pointing out Polaris.

Alternatively, there is another constellation that is helpful in navigating at night: Orion or "The Hunter". This large constellation can be used to determine the east and west cardinal points but is a more time-consuming method of navigation. Orion rises consistently in the East at sundown and sets in the West at sunrise. Using the three bright stars of Orion's belt (the only three stars in the night sky that form a short straight line), one can trace a line from due east to due west as the Hunter travels across the night sky. If one wanted to be highly accurate, the first star in the belt to rise 
and set, called Mintaka, will always rise and set within one degree of true east and true west wherever you are in the world.

Though the techniques discussed here are accurate methods of navigating at night, there are certain things one must remember prior to attempting any of these. The most important thing to keep in mind is not to panic. If you are in a group, stick together and under no circumstances should anyone be sepa- rated from the group. Limited visibility causes the forest to become much more hazardous after sunset. Bear in mind that the techniques and principles of map and compass navigation, such as map analysis that one perfects in daylight, remain the same after dark. Should you choose to attempt celestial navigation keep in mind that this is a technique that takes practice. Try it first in a safe area that you are familiar with-a park or field, a fenced wooded property. Make sure that you are familiar with the techniques of celestial navigation prior to attempting it in the forest and be honest enough with yourself to admit if you are not $100 \%$ sure of what you are doing.

Nicole Bergevin

Marketing Coordinator and FRP/ Institute Knowledge Exchange Specialist

\section{The Great Fire of 1922(The Haileybury Fire)}

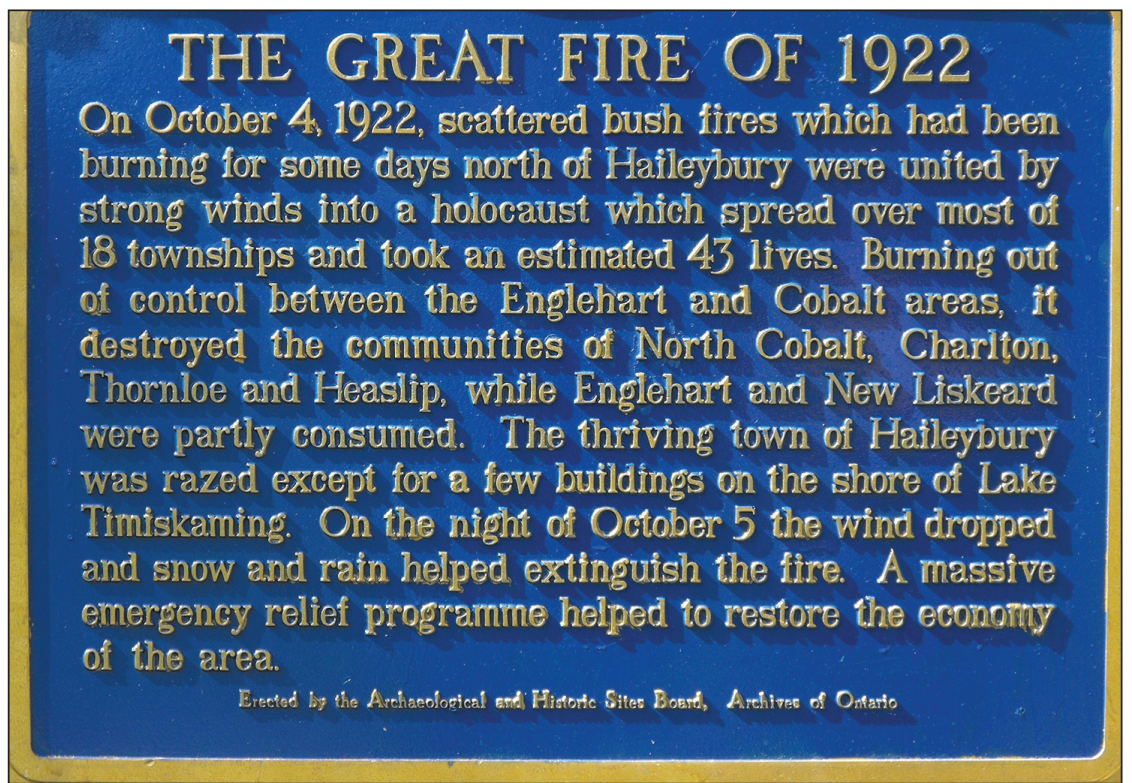

\section{Fire Report}

Place:Haileybury, Ontario;

Size of burn: over 500000 hectares; Number of people affected: 43 people killed;

Property destroyed: around $\$ 8$ million dollars' worth of damages (houses, businesses, churches and many farm animals were all destroyed);

Cause: never determined, although some believed it was arson.

The above historical fire report sums up one of Canada's 10 worst natural disasters. It was devastating to many communities. Eyewitness reports from Haileybury, Ontario and Notre-Damedu-Nord, Quebec provide an idea of the impact the fire had on people that day. Could it happen today? Have we changed enough of our knowledge and improved practices?

"The summer of 1922 was unusually hot and dry in northern Ontario, so hot and dry that worried fire rangers asked the government for permission to stay on for the approaching "burning" season, when farmers were allowed to clear land with small brush fires. Bureaucrats, however, denied the request and on September $12^{\text {th }}$, all fire rangers left the area around Lake Temiskaming. With burning permits now unnecessary, settlers were quick to take advantage and farmers began to set the small fires needed to improve their land. On October $4^{\text {th }}$, gentle fall breezes unexpectedly turned into hurricane-force winds. The small fires, burning on ground dried out from summer heat, soon merged into an inferno. In Haileybury, citizens paid little attention to the smoke, at first no different than the smoke that drifted into town every year during burning season. When the flames approached the town, however, people panicked. In the thick, black smoke, families had difficulty finding each other. A clerk at the telegraph office wired to North Bay, "Haileybury is on Fire. Send help!" Most people headed to the lake, covering themselves with wool blankets, where they waited, shivering, for six hours. By midnight the fire had finally burnt itself out, leaving 90\% of Haileybury in cinders.

\section{Source \\ Haileybury Heritage Museum}

The fire was devastating to residents. Churches that had been built as the town established itself were destroyed as was much of the town. It was definitely time to start over and re-establish the town. It is not as commonly known but 